\title{
ANSERJ
}

Vol. 11, No. 2

Autumn / Automne 2020

pp. 3-7

Canadian Journal of Nonprofit and Social Economy Research

Revue canadienne de recherche sur les OBSL et l'économie sociale

\section{EDITORIAL / ÉDITORIAL}

\section{The Resilient and Innovative Spirit of the Nonprofit and Social Economy Sector / L'esprit résilient et innovateur de l'économie sociale et du secteur à but non lucratif}

\author{
Marco Alberio \\ Alma Mater Studiorum, Università di Bologna \\ Université du Québec à Rimouski
}

\section{Jorge Sousa \\ University of Alberta}

Welcome to the fall issue of The Canadian Journal of Nonprofit and Social Economy Research (ANSERJ).

As we approach the end of 2020, it is always helpful to reflect on the challenges and opportunities that have appeared over the past year. 2020 will always been seen as a year where change was forced upon us, but the responses by nonprofit and social economy organizations have introduced a variety of innovations. Every society has its own dominant form influencing social relations by dictating certain behaviours and attitudes. The contemporary model of society in most Western countries has been a capitalist market society, where market exchange and commodification affirm themselves as major forms of economic integration (Alberio \& Moralli, 2020). However, the emergence or re-emergence of initiatives such as cooperatives, the social economy and the associative sectors in Canada and elsewhere has shown how the boundaries seemed to have weakened between different forms of socioeconomic integration such as redistribution
Nous avons le plaisir de vous présenter le numéro d'automne de la Revue canadienne de recherche sur les OBNL et l'économie sociale (ANSERJ).

La fin de l'an 2020 approche. II est donc souhaitable de réfléchir sur les défis et les occasions qui sont survenus au cours des douze derniers mois. Nous verrons toujours l'an 2020 comme une année où le changement nous a été imposé. Cependant, dans les circonstances, les organismes à but non lucratif et l'économie sociale ont proposé une diversité de solutions innovatrices. Toute société a sa configuration prédominante qui, en prescrivant certains comportements et certaines attitudes, influence les rapports entre ses membres. La forme de société dans la plupart des pays occidentaux est celle d'une économie de marché capitaliste, où les échanges et la marchandisation s'affirment comme des agents majeurs de l'intégration économique (Alberio et Moralli, 2020). Cependant, l'émergence ou la réémergence au Canada et ailleurs d'initiatives comme les coopératives, le secteur associatif et celui de l'économie sociale a montré comment certaines différences sont en train de s'effacer entre diverses formes d'intégration socioéconomique telles que la redistribution 


\section{Editorial / Éditorial (2020)}

traditionally implemented by the State, community reciprocity, and exchange through the market economy.

Hybridization or a blended approach becomes essential in the ongoing processes of social (and forced) transformation that a crisis like the COVID-19 pandemic has exacerbated. Blending can make it easier for societies to adapt to the complex and multifaced transformations that we are all experiencing. Blending approaches to business and determining their impact can bring on new ways to conceive of social phenomena and relationships by creating unique alliances between actors that have traditionally been perceived as incompatible: social movements, political institutions and decision-makers, and the private sector. Several examples of potential alliances have been observed in the last few months of the pandemic, where all actors have been called on to join their efforts in order to face the socioeconomic challenges brought on by the crisis, such as rising inequalities among group populations and territories and within economic and industrial sectors. The critical use of the concept of blending can also bring some confusion in the prerogatives, roles and responsibilities of social economy actors.

From a hybridized or blended perspective, it is very important not to look at nonprofit organizations and social economy actors as being purely charitable. Indeed, they have to balance their social and economic missions (Alberio \& Tremblay, 2014), which means that the crisis could also have an impact on their ability to maintain this balance and could compel them to protect their economic performance at the expense of their social mission. In addition, we should not forget that actors, including social economy and community ones, do not work alone. They are in constant contact with other stakeholders, such as decision-makers, funding institutions, private philanthropy foundations, and so on. We believe that "blending" and "crisis" could be the linking concepts of all the papers presented in this issue.

In this issue, the articles in the "Perspectives for the Field" section highlight responses from different actors who during COVID-19 faced the challenges of meeting traditionnellement effectuée par l'État, la réciprocité communautaire, et l'échange dans une économie de marché.

Une approche hybride ou mixte devient essentielle aux processus de transformation sociale imposés et exacerbés par la pandémie actuelle. Pour les sociétés, cette approche mixte peut faciliter la tâche de s'adapter aux transformations complexes et diverses que nous sommes tous et toutes en train de subir. Recourir à une approche mixte et déterminer l'impact de celle-ci peuvent entraîner de nouvelles manières de concevoir les phénomènes et rapports sociaux en créant des alliances singulières entre des acteurs qu'on a traditionnellement considérés comme incompatibles : les mouvements sociaux, les institutions et décideurs politiques, ainsi que le secteur privé. Dans les premiers mois de la pandémie, on a remarqué plusieurs alliances formées lorsque les parties prenantes ont toutes reçu l'appel de joindre leurs efforts afin de s'opposer aux défis socioéconomiques créés par la crise, tels que les inégalités croissantes dans certaines populations et territoires mais également dans certains secteurs économiques et industriels. D'autre part, l'utilisation critique du concept d'hybridation nous permet de noter également la confusion possiblequant aux prérogatives, rôles et responsabilités des acteurs de l'économie sociale.

D'un point de vue hybride ou mixte, il est très important de ne pas considérer les organismes à but non lucratif et les acteurs de l'économie sociale comme agissant de manière strictement caritative. Au contraire, ceux-ci doivent toujours essayer de garder l'équilibre entre leurs missions sociales et économiques (Alberio \& Tremblay, 2014). Malheureusement, la crise actuelle pourrait avoir un impact sur cette capacité à garder l'équilibre et pourrait les obliger à protéger leur rendement économique au détriment de leur mission sociale. Par surcroît, nous devons nous rappeler que les acteurs, y compris ceux de l'économie sociale et les communautés, n'œuvrent jamais seuls. Ils sont en constante relation avec d'autres parties prenantes tels que les décideurs, les bailleurs de fonds, les fondations philanthropiques privées, etc. Nous croyons donc que « mixage » et " crise » pourraient être les concepts sous-tendant tous les articles du numéro actuel.

Dans ce numéro, les textes dans la rubrique « Perspectives pour le terrain » mettent l'accent sur les réponses provenant de différents acteurs qui, pendant la pandémie, ont surmonté 


\section{Editorial / Éditorial (2020)}

community needs and adapting organizationally. Jeff Loomis writes about how his organization pivoted towards a greater integration of technological tools aimed at supporting the broader community. In their article, Vincent van Schendel and Nancy Neamtan emphasize how the State has invested community actors with specific roles and responsibilities. As always in this kind of State/community relationship, the key is for everyone to assume his or her own responsibilities. The State's responsibility is to ensure that resources, assistance and expertise get to grassroots community actors in order to avoid some of the forms of disengagement that have all too often been observed in the past. Raissa Marks and Michael Toye address these points in their policy positions in which they stress how community economic development activities must play a role in the recovery from COVID-19.

In the first of the five in-depth articles for this issue, Laurie Mook writes about integrated social accounting, which places social and environmental performance alongside financial performance. After dealing with the history of this concept, she concentrates on the most recent developments of what she calls a fourth wave of integrated social accounting, which focuses its attention on the internal and external impacts of an organization's activities through the lens of the sustainable development goals (SDGs). As for Chantale Mailhot, Valérie Michaud and Sonia Tello-Rozas, they focus on the efforts of nonprofit organizations (NPOs) to show that their activities have a visible impact in a context of marketization characterized among other things by a rise in performance measures. Next to their original and main tasks, nonprofit organizations must constantly ensure their own legitimacy, which may have concrete repercussions on their mission. More specifically, the authors deal with consultants retained by a specific NPO to help in the development of an impact evaluation tool aimed at legitimizing its actions. Here, hybridization (in positive as well as negative terms) emerges very clearly, as it does in the cooperation between the NPO's social community actors and the private consultants with whom they have to work. les défis de répondre aux besoins des communautés et d'adapter leurs organisations aux nouvelles conjonctures. Jeff Loomis décrit comment son organisation a effectué une meilleure intégration d'outils technologiques dans le but de mieux appuyer la communauté qu'il dessert. Dans leur article, Vincent van Schendel et Nancy Neamtan soulignent comment l'État a accordé des rôles et des responsabilités spécifiques aux acteurs communautaires. Comme toujours dans ce type de rapport entre l'État et la communauté, l'essentiel est que tous les acteurs puissent pleinement assumer leurs responsabilités. Celle de l'État consiste entre autres à s'assurer que les ressources, l'aide et l'expertise essentielles parviennent aux acteurs communautaires afin d'éviter certaines des formes de désengagement qu'on a trop souvent observées dans le passé. Raissa Marks et Michael Toye quant à eux mettent aussi en évidence ces questions dans leur article dans lequel ils soulignent combien les activités de développement économique communautaire ont un rôle important à jouer dans l'après-COVID-19.

Dans le premier des cinq articles plus longs paraissant dans ce numéro, Laurie Mook écrit sur la comptabilité sociale intégrée, qui place le rendement social et environnemental au même niveau que le rendement financier. Après avoir présenté l'histoire du concept, elle se concentre sur les développements les plus récents dans ce qu'elle appelle une quatrième vague de comptabilité sociale intégrée, qui porte son attention sur les effets internes et externes des activités d'une organisation du point de vue des objectifs de développement durable (ODD). Quant à l'article de Chantale Mailhot, Valérie Michaud et Sonia Tello-Rozas, les auteures prennent en considération les organismes à but non lucratif (OBNL) afin de montrer que les activités de ceux-ci ont un impact significatif dans un contexte de marchandisation caractérisé entre autres par l'importance croissante accordée aux mesures de performance. Les OBNL, en plus de leurs responsabilités principales qui sont leur raison d'être, doivent sans cesse assurer leur propre légitimité, ce qui peut avoir des conséquences néfastes sur leur capacité à atteindre leurs objectifs. Plus particulièrement, les auteures traitent des consultants employés par un OBNL pour aider au développement d'un outil d'évaluation qui pourrait mieux légitimer ses actions. Ici, l'hybridation (sous son acception positive et négative) se manifeste clairement aussi dans la collaboration entre les acteurs de l'OBNL et les consultants privés avec lesquels ils doivent travailler. 


\section{Editorial / Éditorial (2020)}

In their contribution, Mebometa Ndongo and Juan-Luis Klein focus on the African continent and on the emergence of social innovation as an original concept for local and regional development. The article's aim is to explore and highlight the emerging trajectories of social innovation, which until now has received little consideration in Africa. Through a critical revisitation of the literature, the authors explore several emblematic cases from the 1960s to the present, when the confrontation between development initiatives amidst multiple crises and historical realities has generated what they call a hybridization that articulates innovations. Blending is also present as far as knowledge and skills are concerned. Indeed, there exists a set of operational logics marked by the interaction of imported technologies and pre-existing mechanisms from which innovative technologies can originate.

The article by Alexis Buettgen and Thomas R. Klassen is based on an exploratory study analyzing the role of the nonprofit sector as a site for inclusivity, particularly for disabled people. Using secondary data as well as indepth interviews with the staff of NPOs, they identify the benefits that can accrue-to individuals, organizations and communities-when agencies in the nonprofit sector employ people with disabilities. Blending here is not only present in the nature of the nonprofit organization itself, which is a hybrid entity with both an economic and social mission, it is also present in social relations within the organization. The authors observe that the co-presence of disabled and non-disabled employees clearly has a positive impact in the workplace, increasing awareness and sensitivity among all the workers, conferring value on disability through an explicit recognition of what everyone can contribute, and clarifying the notion of dependence. The article by Gregor Rabong and Dietmar Rossel explores the notion of hybridization in an organizational context by applying it to the study of credit cooperatives in Austria. The coauthors emphasize how credit cooperatives are gradually developing from being purely member-focused to being somewhat third party-focused cooperatives striving for the common good. In addition, they question whether this hybridization is in the members' interests or not.
Dans leur contribution, Mebometa Ndongo et Juan-Luis Klein portent leur attention sur le continent africain et sur l'innovation sociale comme concept original dans le contexte du développement local et régional. Le but de leur article est d'explorer et de souligner les trajectoires émergentes en innovation sociale, un concept ayant jusqu'à présent reçu peu d'attention en Afrique. Par une revue critique de la littérature, les auteurs explorent plusieurs cas emblématiques des années 1960 jusqu'au présent, quand la confrontation entre les réalités historiques et les initiatives de développement dans un contexte de crises multiples a engendré ce qu'ils appellent une " hybridation qui articule les innovations ». Cette hybridation est présente aussi dans le savoir et les compétences. En effet, il existe des logiques opérationnelles marquées par les interactions entre technologies importées et mécanismes préexistants à partir desquels il est possible de créer des technologies innovatrices.

L'article d'Alexis Buettgen et de Thomas R. Klassen se fonde sur une étude exploratoire sur le rôle du secteur à but non lucratif comme lieu d'inclusivité, particulièrement pour les personnes en situation d'handicap. Se basant sur des données secondaires et sur des entretiens en profondeur avec le personnel d'OBNL, ils identifient les bienfaits qui se présentent-pour les particuliers, les organismes et les communautés-quand les agences du secteur à but non lucratif emploient des personnes en situation d'handicap. Le mixage dans ce cas est présent dans I'OBNL lui-même, cette entité hybride combinant une mission économique et sociale. En outre, il est présent dans les relations sociales au sein de I'organisation. Les auteurs observent en effet que la coprésence d'employés en situation d'handicap et d'autres en situation de non-handicap a clairement un impact positif sur le milieu du travail. En effet, cette coprésence augmente la conscientisation et la sensibilisation de tous les employés, accorde de la valeur aux personnes en situation d'handicap par une reconnaissance explicite de ce que tous et toutes peuvent contribuer, et nuance la notion de dépendance. Quant à l'article de Gregor Rabong et de Dietmar Rossel, il explore la notion d'hybridation dans un milieu organisationnel en se penchant sur les coopératives de crédit en Autriche. Les auteurs soulignent comment les coopératives de crédit sont en train d'évoluer petit à petit, d'organismes strictement centrés sur leurs membres en organismes centrés dans une certaine mesure sur des tiers dans le but d'accroître le bien commun. 


\section{Editorial / Éditorial (2020)}

Each of the articles in this issue provides an important message to the various stakeholders who will be involved in the socioeconomic recovery from COVID-19. We do want to note however that in most cases the articles were written before COVID-19's appearance as a complex global phenomenon.

We hope that you enjoy this issue. If you have not done so already, please register on the ANSERJ website so that you can receive updated information and announcements about the journal. We always welcome feedback and suggestions.

We conclude this editorial by acknowledging the passing of Dr. John Loxley in July 2020. John was a founding member of our editorial board. His work led to a better understanding of the political and economic impact of policies and practices associated with the social economy. He left behind an important legacy, and his presence and support will be sorely missed.

\section{REFERENCES}

Alberio, M. \& Moralli, M. (2020). Social innovation in alternative food networks. The role of co-producers in Campi Aperti. Journal of Rural Studies, 80 , in press. doi:10.1016/j.jurstud.2020.10.007

Alberio, M. \& Tremblay, D.G. (2014). De la vision à l'action : la performance dans les enterprises d'insertion du Québec. Canadian Journal of Nonprofit and Social Economy Research Revue canadienne de recherche sur les OBSL et l'économie sociale, 5(1), pp. 21-40. doi:10.22230/cjnser.2014v5n1 a168
Les deux auteurs se demandent si cette hybridation sert ou non les intérêts des membres.

Chacun des articles dans ce numéro offre un message important aux diverses parties prenantes qui devront participer à la reprise socioéconomique de l'après-COVID-19. Nous voulons toutefois souligner que dans la plupart des cas ces articles ont été écrits avant la survenue de la pandémie comme phénomène mondial complexe.

Dans l'espoir que vous aimerez ce numéro, si vous ne l'avez pas déjà fait, nous vous invitons à vous inscrire sur le site de la Revue canadienne de recherche sur les OBNL et l'économie sociale (ANSERJ) afin de recevoir des mises à jour et d'autres informations sur la revue. D'autre part, sachez que nous sommes toujours vivement intéressés à recevoir vos commentaires et suggestions.

Nous tenons à conclure cet éditorial en signalant le décès du Dr. John Loxley en juillet 2020. John était un membre fondateur de notre comité de rédaction. Son travail a mené à une meilleure compréhension de l'impact politique et économique de l'économie sociale. II laisse une marque importante, et sa présence et son appui nous manqueront énormément.

\section{RÉFÉRENCES}

Alberio, M., \& Moralli, M. (2020). Social innovation in alternative food networks. The role of co-producers in Campi Aperti. Journal of Rural Studies, 80, in press. doi : 10.1016/j.jurstud.2020.10.007

Alberio, M., \& Tremblay, D.G. (2014). De la vision à l'action : la performance dans les enterprises d'insertion du Québec. Canadian Journal of Nonprofit and Social Economy Research/Revue canadienne de recherche sur les OBSL et l'économie sociale, 5(1), pp. 21-40. doi : 10.22230/cjnser.2014v5n1a168 